\title{
Beliefs about Learning and Teaching Communicative English in Japan
}

\author{
Hiroko Matsuura \\ Fukushima University
}

Reiko Chiba

Asia University

\section{Paul Hilderbrandt \\ Meiji Gakuin University}

This study examines Japanese university EFL student and teacher beliefs about learning and teaching communicative English in Japan. Over 300 students and 82 college teachers were given a 36 -item questionnaire to assess their beliefs about (a) important instructional areas, (b) goals and objectives, (c) instructional styles and methods, (d) teaching materials, and (e) cultural matters. The results indicate that many students preferred traditional styles of ELT pedagogy including a teacher-centered approach (listening to lectures), learning isolated skills (pronunciation), and focusing on accuracy (Japanese translation). On the other hand, the teachers' preferences appeared to have shifted towards more recent pedagogy such as a learner-centered approach, integrated skills, and a focus on fluency. These results suggest that constant assessment of student beliefs is essential to link ELT theories and classroom practice.

本研究は、コミュニケーションを目的とする英語教育及び学習に対する日本 人大学生と教師の認識について調査したものである。300人以上の学生と8 2 大学の教師がく被験者〉として教授領域、目摽・目的、教授法、教材、文化 的側面をめぐる36項目の質問紙に答えた。学生被験者の多くは、教師中心のア プローチ (例、詇義)、独立したスキル（例、発音)、正確さ（例、日本語 訳）などで表現される伝統的な教授スタイルを好む傾向を示した。一方、鞂師 の側は、学習者中心のアプローチ、統合的スキル、流暢さなどをキーワードと するより新しい教授スタイルに暂好が移行している。本研究結果は、教授理論 と教室での実践との関係をより向上させるためには、英語教育に対する学習者 の考えを継統的に調泴することが重要であることを示唆している。

D nglish education in Japan has seen a number of changes over the past 15 years. The Ministry of Education (MOE) has initidated several reforms at the secondary school level aimed at changing the prevailing system of English education, often dominated by 
grammar-translation pedagogy, to one with a stronger emphasis on communication. The first of two prominent reforms is the JET (Japan Exchange and Teaching) Program, in which native English speaking ALTs (Assistant Language Teachers) team teach public school English classes with Japanese teachers of English (JTEs) (Ministry of Foreign Affairs, 2000). In 1999 alone 5,241 ALTs were appointed to junior and senior high schools throughout Japan (Ministry of Education, 1999a). The second MOE initiative was the 1994 introduction of a new high school subject, Oral Communication, consisting of three courses on listening, speaking, and discussion/debate. Many high schools have implemented this program and use oral communication textbooks screened and approved by MOE officials. Thus English education in Japan has progressed in the direction of teaching the language for communication.

At the university level as well, teaching and learning communication skills in English is now considered to be important. In November, 1999 the MOE asked one of its advisory boards to consider what language education ought to consist of, and in particular, to recommend how communication skills could be improved (Ministry of Education, 1999b). Recognizing that English is an important means of communication, the advisory board emphasized the need for increased English ability for all students, especially in the areas of listening and speaking (Ministry of Education, 2000). However, despite this stress on the communicative use of English, neither the MOE nor the advisory board has provided guidance as to pedagogical goals, objectives, or teaching methods for communicative English instruction. Therefore in practice these remain quite diverse, with unpredictable and unreliable outcomes. Unlike secondary school classes, university English classes need not use MOE-approved English textbooks, so there is a range of material and course designs. Thus both students and teachers continue to hold various beliefs about how English should be learned.

\section{Learner and Teacher Beliefs about Language Learning}

Learner beliefs about language learning is an important research area in ESL/EFL. As Horwitz (1988) pointed out, investigating learners' beliefs has "relevance to the understanding of their expectations of, commitment to, success in, and satisfaction with language classes ${ }^{n}$ (p. 283). Although few researchers have examined students' beliefs about language learning (see Wenden, 1986; Horwitz, 1988; Mori, 1999), students hold various ideas and beliefs as to how they can better learn a 
language and how teachers can help them. It is worthwhile, therefore, to investigate how student beliefs differ from teacher beliefs because such differences can influence the effectiveness of classroom instruction.

\section{Learner Beliefs}

A study by Horwitz (1988) investigated beliefs of university students in beginning-level foreign language classes. Using the BALLI (Beliefs About Language Learning Inventory) scale (Horwitz, 1985), Horwitz assessed student beliefs in five areas: (a) difficulty of language learning, (b) foreign language aptitude, (c) the nature of language learning, (d) learning communication strategies, and (e) motivations and expectations. Wenden (1986) also examined learner beliefs about second language learning by interviewing a group of adult ESL learners in advancedlevel English classes in the U.S.A. and classifying their responses into five categories: (a) designating (language), (b) diagnosing (language proficiency), (c) evaluating (outcome of strategies), (d) self-analyzing (personal factors), and (e) theorizing (how best to approach language learning).

\section{Teacher Beliefs}

Other researchers have investigated beliefs and attitudes held by teachers (see Wolf \& Riordan, 1991; Chiba \& Matsuura, 1998; Renandya, Lim, Leong \& Jacobs, 1999). Wolf and Riordan (1991), for example, conducted a survey on attitudes of foreign language teachers toward curriculum, instruction, and assessment practices. Their survey included two instructional approaches, a traditional approach and a teaching-for-proficiency approach. Teachers who preferred the traditional approach were likely to agree with such questionnaire items as "In introductory classes students should focus only on the grammar mechanics of the language," and "Direct translation into the native language is the most effective way to evaluate reading comprehension" (p. 475). On the other hand, teachers who preferred the teaching-forproficiency approach were likely to think that "Teachers should evaluate communication activities by the success of the communication," and "Teachers should include some communication activities in student evaluation procedures at all levels of instruction" (p. 476). For this group the traditional teaching approach received either "disagree" or "strongly disagree" as responses while the teaching-for-proficiency approach elicited either "agree" or "strongly agree" reactions.

In a survey of teacher attitudes in Japan, Chiba and Matsuura (1998) 
reported findings from a Japanese university freshman EFL program where native English speakers and Japanese teachers team taught the same classes. The researchers examined differences in ideas about course objectives, teaching styles, materials, and cultural concerns between native English speaking teachers and Japanese teachers of English, and the results indicated some differences in teaching styles between the two groups. The native English speaking teachers tended to believe more strongly than their Japanese counterparts that group work and game-oriented activities are effective for Japanese students. While most Japanese teachers of English felt that using the students' first language (L1) is helpful or necessary, most native English speaking teachers disagreed with the idea of using the students' L1 in English class. Furthermore, the Japanese teachers of English were relatively strict regarding their students' linguistic errors, whereas the native English speaking teachers tended to show more tolerance toward errors.

\section{Research Focus}

The present study uses a questionnaire to examine Japanese university EFL students' beliefs about learning and teaching communicative English and compares them with those of university EFL teachers. The research questions are:

1. What instructional areas do Japanese university EFL students and teachers believe are important in learning and teaching communicative English?

2. How do both groups think that students can best approach English in the Japanese university EFL classroom?

3. How do Japanese university EFL student beliefs differ from teacher beliefs?

\section{Method}

Subjects

\section{Students}

The 301 participants in this study were enrolled in English classes taught by the three investigators at three universities in Tokyo, Fukushima, and Kanagawa and thus constitute a convenience sample. They were all native Japanese speakers studying English as a foreign language (EFL). Their average age was 19.6 years old with a range of 18 to $26 ; 85$ were male and 211 were female and five were of unknown gender. One hun- 
dred forty-two students (47\%) were majoring in English, $84(27.9 \%)$ in economics, $61(20.3 \%)$ in education, $10(3.3 \%)$ in international relations, and $4(1.3 \%)$ in other fields.

\section{Teachers}

A convenience sample of 82 Japanese college and university English teachers collaborated in this study. The teachers included colleagues of the investigators as well as volunteers recruited at a professional conference and through the Internet. Forty-one were native English speakers and 41 were native Japanese speakers, with an average age of $42.1(S D=8.9)$ and $45.8(S D=12.1)$ respectively. The native English speaker group consisted of 29 Americans, seven British, three Canadians, and two Irish. Their average length of stay in Japan was 8.77 years, with a range of four months to 35 years. Sixty teachers $(73.2 \%)$ were teaching General English, 55 (67.1\%) were teaching Listening, 52 (63.4\%) were teaching Speaking, 54 (65.9\%) were teaching Reading, and $63(76.8 \%)$ were teaching Writing. The length of their teaching experience ranged from two years to 45 years, with an average of 15.88 years.

\section{Questionnaires}

Two questionnaires were developed, one for the students and the other for the teachers. Each consisted of 36 statements followed by a 6 -point Likert scale to indicate agreement or disagreement. The investigators decided to use a 6-point scale rather than a 7-point scale hoping that subjects would more clearly indicate either positive or negative attitudes toward each questionnaire item. The subjects were asked to read each statement and indicate their reaction by choosing a number from 1 (strongly agree) to 6 (strongly disagree). The questionnaires were constructed by modifying the questionnaire Chiba and Matsuura (1998) used previously, adding items to elicit subjects' beliefs regarding important aspects for communicative language learning and teaching.

The student version of the questionnaire was written in Japanese and elicited beliefs about learning. The teacher version was written in English and elicited beliefs about teaching. Although the wording of the two questionnaires was not the same, the statements in both aimed to assess a variety of beliefs in the following five categories: (a) important instructional areas in communicative language learning and teaching, (b) goals and objectives, (c) teaching styles and methods, (d) teaching materials, and (e) cultural matters. Aspects of communicative language learning and teaching included such instructional areas as lis- 
tening, speaking, reading, writing, grammar, pronunciation, culture, and language function. The term "styles" in "teaching styles" simply referred to methods of teaching and did not indicate aspects of individual differences such as cognitive styles (e.g., field-dependence vs. field-independence) or the affective styles (e.g., ambiguity tolerance vs. ambiguity intolerance) which have been investigated in language learning and teaching research (see Ehrman \& Oxford, 1990; Reid, 1995).

\section{Data Collection Procedures}

The investigators distributed the student version of the questionnaire during regular EFL classes at three universities where they were teaching. Response was optional. The teacher version of the questionnaire was distributed as printed copies and on the Internet. Hard copies, with a return envelope, were handed out to approximately 70 college English teachers at a professional conference and at the schools where they worked. Nearly $90 \%$ of the teachers answered the questionnaire. The Internet home page address, attached to e-mail messages requesting collaboration, was sent out to approximately 200 teachers randomly selected from a member list of an academic organization for college EFL teaching. Only about $10 \%$ of those who received the e-mail responded to the web version of the questionnaire. The investigators speculated that one reason for the low return rate was that the e-mail request could be ignored relatively easily, especially when the e-mail receiver did not know who the senders were. Another reason was caused by technical problems with the software. The investigators received messages from several e-mail recipients reporting that they could not access the web page. Better ways of collecting data through the Internet need to be developed for future studies.

\section{Data Analyses}

As stated earlier, the students and teachers in this study answered two different questionnaires, the student version written in Japanese and the teacher version written in English. The stimulus statements in both versions were developed so that students and teachers could indicate their beliefs regarding common concepts. Consequently, the wording and perspectives of each statement were not always identical so it was impossible to compare the answers of students and teachers directly and statistically. For example, Item 12 in the student version was intended to elicit general views of the communicative English classroom through the statement, "Speaking is an important aspect of learning 
communication. ${ }^{\circ}$ On the other hand, the statement in the teacher version was intended to investigate how many teachers taught speaking in their class and was worded "Speaking is an important aspect of teaching communication in my class."

The following sections compare the percentages of students and teachers who were positive or negative toward each questionnaire item. In addition, some perceptual differences between native English speaking teachers and Japanese teachers of English are analyzed in terms of teaching communicative English. For this purpose independent $t$-tests followed by a Bonferroni correction were used to determine the significance of differences between the responses of the English native speaker teachers and the Japanese teachers to nine items reflecting the four skills of English, cultural aspects, speech functions, and nonverbal communication: Item 6, Functions; Item 12, Speaking; Item 15, Grammar; Item 19, Listening; Item 23, Cultural differences; Item 25, Reading; Item 30, Non-verbal cues; Item 31, Pronunciation; and Item 35. Writing.

\section{Results \\ Beliefs about Important Instructional Areas}

As shown in Table 1, the students tended to consider the nine aspects of the questionnaire (i.e, functions, speaking, grammar, listening, cultural differences, reading, non-verbal cues, pronunciation, and writing) important for learning communicative English. However the traditional instructional areas (reading, writing, and grammar) were not considered as important as speaking and listening. The teachers' views were similar to the students' views except for pronunciation (Item 31). Here only $68.3 \%$ of the teachers indicated that they emphasized teaching pronunciation, whereas more than $91 \%$ of the students indicated that learning correct pronunciation was important.

As shown in Table 2, the teachers' native language appeared to influence their responses. As measured by independent $t$-tests comparing the mean scores for the nine questionnaire aspects, the native English speaking teachers and the Japanese teachers of English gave significantly different responses to most of the items except for Items 15, 25 , and 35 . However, after application of the Bonferroni correction procedure (dividing the alpha level of .05 by the number of $t$-tests performed [nine], giving a very conservative significance level of .0056 ), only Items 12 (Speaking) and 30 (Non verbal cues) were significantly different between the two groups of teachers. This difference suggested the presence of different attitudes regarding instructional areas other than grammar, reading, and writing, traditionally well- 


\begin{tabular}{|c|c|c|c|c|c|c|c|c|}
\hline & & - & $\begin{array}{l}\text { strongly } \\
\text { agree }\end{array}$ & agree & $\begin{array}{l}\text { slightly } \\
\text { agree }\end{array}$ & $\begin{array}{l}\text { slightly } \\
\text { disagree }\end{array}$ & disagree & $\begin{array}{l}\text { strongly } \\
\text { disagree }\end{array}$ \\
\hline \multirow[t]{2}{*}{6.} & (S) & $\begin{array}{l}\text { Leaming abour fonctional language such as asking for information and apologizing is } \\
\text { important for communication. }\end{array}$ & 33.2 & 33.2 & 21.6 & 8.3 & 2.7 & 1.0 \\
\hline & $(\mathrm{T})$ & $\begin{array}{l}\text { Functional language such as asking for information and apologizing is an important } \\
\text { aspect of teaching communication in my class. }\end{array}$ & 19.5 & 25,6 & 25.6 & 11.0 & 15.9 & 1.2 \\
\hline \multirow[t]{2}{*}{12.} & (S) & Speaking is an important aspect of leaming communication. & 42.5 & 38.5 & 15.3 & 2.3 & 1.3 & 0.0 \\
\hline & (T) & Speaking is an important aspect of teaching communication in my class. & 39.0 & 29.3 & 13.4 & 13.4 & 3.7 & 1.2 \\
\hline \multirow[t]{2}{*}{ 15. } & (S) & Grammar is an important aspect of leaming communication. & 5,6 & 17.3 & 36.5 & 27.2 & 10.3 & 3.0 \\
\hline & (T) & Grammar is an important aspect of teaching communication in my class. & 2.4 & 17,1 & 28.0 & 22.0 & 23.2 & 4.9 \\
\hline \multirow[t]{2}{*}{19.} & (S) & Listening is an important aspect of learning communication. & 33.2 & 42.5 & 18.3 & 2.7 & 1.3 & 0.3 \\
\hline & (T) & Listening is an important aspect of teaching communication in my class. & 35.4 & 37,8 & 17.1 & 6.1 & 2.4 & 0.0 \\
\hline \multirow[t]{2}{*}{23.} & $(S)$ & Learning about cultural differences is important for communication. & 26.9 & 32.9 & 30.6 & 6.0 & 1.3 & 0.7 \\
\hline & (T) & Teaching about cultural differences is an important aspect of my class. & 20.7 & 37.8 & 26.8 & 7.3 & 4.9 & 1.2 \\
\hline \multirow[t]{2}{*}{25} & (S) & Reading is an important aspect of leaming communication. & 13.0 & 19.6 & 36.2 & 22.3 & 6.0 & 1.7 \\
\hline & (T) & Reading is an important aspect of teaching communication in my class. & 4.9 & 18.3 & 45.1 & 17.1 & 9.8 & 2.4 \\
\hline \multirow[t]{2}{*}{ 30. } & (S) & Learning about non-verbal cues is important for communication. & 14.6 & 23.3 & 30.9 & 21.9 & 6.6 & 1.3 \\
\hline & (T) & Non-verbal cues are important aspects of teaching communication in my class. & 3.7 & 17,1 & 41.5 & 17.1 & 12.2 & 7.3 \\
\hline \multirow[t]{2}{*}{31.} & (S) & Learning correct pronunciation is important for communication. & 29.2 & 37.5 & 24.6 & 5.0 & 1.7 & 0.3 \\
\hline & (T) & Pronunciation is an important aspect of teaching communication in my class. & 4.9 & 26.8 & 36.6 & 18.3 & 7.3 & 4.9 \\
\hline \multirow[t]{2}{*}{35.} & (S) & Writing is an important aspect of learning commurication. & 1.3 & 23.6 & 36.5 & 21.9 & 3.0 & 2.0 \\
\hline & $(\mathrm{T})$ & Writung is an important aspect of teaching communication in my class. & 8.5 & 32.9 & 32.9 & 14.6 & 9.8 & 1.2 \\
\hline
\end{tabular}


covered areas in educational settings in Japan, and should be investigated further.

Table 2: Differences between Native English Speaking Teachers and Japanese Teachers

\begin{tabular}{|c|c|c|c|c|}
\hline & $\begin{array}{c}\text { Native } \\
M(S D)\end{array}$ & $\begin{array}{c}\text { Japanese } \\
M(S D)\end{array}$ & 1 & $p$ \\
\hline 6. Functions & $2.43(1.32)$ & $3.20(1.35)$ & -2.60 & * \\
\hline 12. Speaking & $1.46(0.74)$ & $2.88(1.27)$ & -6.16 & $* * *$ \\
\hline 15. Grammar & $3.75(1.19)$ & $3.50(1.28)$ & 0.90 & \\
\hline 19. Listening & $1.71(0.68)$ & $2.33(1.19)$ & -2.89 & $* *$ \\
\hline 23. Cultural differences & $2.12(0.78)$ & $2.70(1.34)$ & -2.38 & * \\
\hline 25. Reading & $3.25(0.93)$ & $3.08(1.23)$ & 0.72 & \\
\hline 30. Non-verbal cues & $2.76(0.92)$ & $4.05(1.18)$ & -5.52 & $* * *$ \\
\hline 31. Pronunciation & $2.85(0.88)$ & $3.38(1.39)$ & -2.02 & * \\
\hline 35. Writing & $3.05(0.97)$ & $2.70(1.29)$ & 1.35 & \\
\hline
\end{tabular}

\section{Beliefs about Goals and Objectives}

Students and teachers displayed similar beliefs about the goals and objectives of English learning and teaching (Table 3). Most students believed that learning to respond to each other and to interact with their teachers are necessary (Items 7 and 11). A majority also believed that knowledge of Western-style learning strategies and communication styles is important (Item 17). Furthermore, nearly two thirds of the students believed that teachers should not focus on grammar (Item 22). Likewise, teachers tended to think that students should learn to respond to each other, have more interaction with their teachers, and adopt different learning strategies and communication styles. In addition, $59.8 \%$ of the teachers believed that they do not focus only on teaching grammar.

On the other hand student beliefs were quite different from those of the teachers for six items. More than $67 \%$ of the students thought that their teachers should ask them what they want to learn in class. 


\begin{tabular}{|c|c|c|c|c|c|c|c|c|}
\hline & & & $\begin{array}{l}\text { strongly } \\
\text { agree }\end{array}$ & agree & $\begin{array}{l}\text { slightly } \\
\text { agree }\end{array}$ & $\begin{array}{l}\text { slightly } \\
\text { disagree }\end{array}$ & disagree & $\begin{array}{l}\text { strongly } \\
\text { disagree }\end{array}$ \\
\hline \multirow[t]{2}{*}{4.} & (S) & Teachers should let students decide what they want to do in class. & 10.6 & 21.9 & 34.6 & 21.3 & 8.0 & 3.0 \\
\hline & $(\mathrm{T})$ & I often let students decide what they want to do in class. & 6.1 & 15.9 & 24.4 & 159 & 25.9 & 11.0 \\
\hline \multirow[t]{2}{*}{2.} & (S) & $\begin{array}{l}\text { It is necessary to transiate English sentences into Japanesc to check my reading } \\
\text { comprehension. }\end{array}$ & 10.0 & 29.9 & 27,9 & 19.3 & 7.6 & 4.3 \\
\hline & ( $\mathrm{T}$ ) & Translation into Japanese is an effective way to evaluate reading corruprehension skills. & 1.2 & 17,1 & 30.5 & 9.8 & 25.6 & 12.2 \\
\hline \multirow[t]{2}{*}{ 3, } & (S) & It is necessary for English to be a required course at university level in Japan. & 32.9 & 29,6 & 17,3 & 13.0 & 4.7 & 2,3 \\
\hline & (T) & It is necessary for English to be a requited course at university level in Japan. & 20.7 & 25.6 & 11.0 & 9.8 & 23.2 & 8.5 \\
\hline & (S) & Responding to each other is an important part of communication. & 25.6 & 32.2 & 27.2 & 11,0 & 2,3 & 1.7 \\
\hline & $(\mathrm{T})$ & I teach my students that responding to each other is an impartant part of communication. & 42.7 & 36.6 & 13.4 & 2.4 & 3,7 & 0.0 \\
\hline & (S) & "Interaction " and "communication" mean the same thing. & 46.5 & 42.5 & 8.3 & 1.3 & 0.3 & 1.0 \\
\hline & (T) & "Interaction " and "communication" mean the same thing. & 2.4 & 13.4 & 17.1 & 18.3 & 34.1 & 14.6 \\
\hline & (S) & I don't want my leacher to correct my grammatical mistakes. & 0.7 & 1.3 & 9.6 & 26.2 & 32.9 & 29.2 \\
\hline & & I seldorn correct my students' grammatical mistakes. & 1,2 & 13.4 & 29.3 & 25.6 & 25.6 & 3.7 \\
\hline \multirow[t]{2}{*}{10.} & (S) & $\begin{array}{l}\text { Teachers should put more emphasis on speaking and listening rather than writing and } \\
\text { reading. }\end{array}$ & 40.2 & 30.2 & 18.9 & 7.0 & 3.0 & 0.7 \\
\hline & (T) & I put more emphasis on speaking and listening than writing and reading. & 13.4 & 31.7 & 14.6 & 17.1 & 14.6 & 4.9 \\
\hline & (S) & I want to interact with my teacher in English. & 20.9 & 22.9 & 30.9 & 17,9 & 5,0 & 2.0 \\
\hline & (T) & Japenese students in the English classroom need to be taught to interact with the teacher. & 29.3 & 32.9 & 22.0 & 8.5 & 7.3 & 0.0 \\
\hline & (S) & It is important to learn different learning strategics such as positive participation. & 22.6 & 30.6 & 30.6 & 12.0 & 3.0 & 1.3 \\
\hline & (T) & It is important to teach different learning strategies such as posibive participation. & 25.6 & 48.8 & 20.7 & 2.4 & 0,0 & 0.0 \\
\hline & (S) & 1. want to learn comrnunication skills such as interrupting and nura-taking. & 11.3 & 20.6 & 34.6 & 23.3 & 6.3 & 2.3 \\
\hline & $(\mathrm{N})$ & $\begin{array}{l}\text { Japanese students need to learn communication skilis such as internupting and } \\
\text { turn-taking. }\end{array}$ & 12.2 & 41.5 & 31.7 & 6.1 & 6.1 & 0.0 \\
\hline & (S) & Teachers should not focus on teaching grammar. & 11.3 & 18.9 & 28.9 & 22.9 & 11.6 & 5.0 \\
\hline & (T) & I don't focus on teaching grammar. & 9.8 & 29.3 & 20.7 & 23.2 & 8.5 & 7.3 \\
\hline
\end{tabular}


However, the teachers were divided about who should decide class objectives (Item 1). Furthermore, more than $67 \%$ of the students thought that Japanese translation is necessary for English reading comprehension, whereas nearly half (47.6\%) of the teachers were against the use of translation for evaluating reading comprehension (Item 2). Most students felt that English should be a required course at the university level, whereas the teachers' beliefs were divided (Item 3). While $46.3 \%$ of the teachers agreed with this, $31.7 \%$ disagreed either strongly or moderately. Additionally, a majority of the students tended to believe that "interaction" and "communication" are the same or have quite similar meanings (Item 8 ) whereas $67 \%$ of the teachers disagreed. Moreover, the teachers' ideas about correcting grammatical mistakes were different from those of students (Item 9). While $88 \%$ of the students indicated that they wanted their teachers to correct their grammar mistakes, $14.6 \%$ of the teachers indicated that they seldom correct their students' mistakes, with only $54.9 \%$ correcting mistakes. Furthermore, while nearly $90 \%$ of the students indicated that teachers should put more emphasis on listening and speaking (Item 10), the percentage of teachers who actually emphasized these areas more than reading and writing was much lower, at $59.7 \%$. This final point was perhaps related to the instructional areas of the teacher, since the number who were teaching reading and writing combined $(n=117)$ was a little greater than those who were teaching listening and speaking ( $n=107)$.

\section{Beliefs about Instructional Styles and Methods}

As shown in Table 4, there were similarities and differences between student beliefs and teacher beliefs regarding instructional styles. Both students and teachers agreed that group work and paired activities are appropriate for Japanese students. For Items 14 and 27, a number of students and teachers supported the ideas that working in a group is more effective than individual work and that paired activities are a productive use of class time. Many in both groups indicated that some knowledge of the Japanese language is needed for teachers to analyze students' mistakes and to explain grammar points (Items 33 and 36). A majority of both groups disagreed with the idea of game-oriented activities being childish, although a larger percentage of students $(84.3 \%)$ than teachers (67\%) disagreed with the idea.

While a large majority of the teachers $(92.7 \%)$ wanted feedback on how their students feel about their class, only $3.7 \%$ of the students strongly agreed that they want to talk to their teachers about their feelings and $8.6 \%$ moderately agreed with this idea (Item 13 ). In addition a high percentage of students $(80.4 \%$ ) supported the idea that listening 


\begin{tabular}{|c|c|c|c|c|c|c|c|}
\hline & & $\begin{array}{l}\text { strongly } \\
\text { agree }\end{array}$ & agree & $\begin{array}{c}\text { slightly } \\
\text { agree }\end{array}$ & $\begin{array}{l}\text { slightly } \\
\text { disagree }\end{array}$ & disagree & $\begin{array}{l}\text { strongly } \\
\text { disagree }\end{array}$ \\
\hline \multirow[t]{2}{*}{13.} & I want to talk to my teacber how I feel about our class. & 3.7 & 8.6 & 27.9 & 43.9 & 11.6 & 4.0 \\
\hline & I always want to know how students feel about my class. & 23.2 & 39.0 & 30.5 & 7.3 & 0.0 & 0.0 \\
\hline \multirow[t]{2}{*}{14.} & $\begin{array}{l}\text { Working in a group is more effective than individual work to improve my } \\
\text { English proficiency. }\end{array}$ & 6.0 & 24.9 & 32.2 & 28.2 & 6.6 & 2.0 \\
\hline & $\begin{array}{l}\text { Working in a group is more effective than individual work for Japanese students to } \\
\text { improve their proficiency in English. }\end{array}$ & 14.6 & 30.5 & 22.0 & 15,9 & 7.3 & 7.3 \\
\hline \multirow{2}{*}{16.} & Game-oriented activities are childish for university level students. & 1.0 & 4.7 & 10,0 & 29.2 & 31.2 & 23.9 \\
\hline & Game-oriented activities are childish for university level studenls. & 3.7 & 13,4 & 14.6 & 8.5 & 32.9 & 25.6 \\
\hline \multirow{2}{*}{27.} & Paired activities are productive uses of language class time. & 10.0 & 29.6 & 32.6 & 21.9 & 4.0 & 0.7 \\
\hline & Paired activities are productive uses of language class time. & 20.7 & 37.8 & 28,0 & 1.2 & 4.9 & 6.1 \\
\hline \multirow{2}{*}{$\begin{array}{ll}28 . & (\mathrm{S}) \\
(\mathrm{T})\end{array}$} & Listening to a lecture about a certain topic is an effective way of leaming English. & 12.3 & 29.9 & 38.2 & 14.0 & 4.0 & 0.3 \\
\hline & $\begin{array}{l}\text { Giving a lecture about a certain topic is an effective way of teaching English to } \\
\text { Japanese students. }\end{array}$ & 2.4 & 13.4 & 29.3 & 20.7 & 24.4 & 8.5 \\
\hline \multirow[t]{2}{*}{ (S) } & $\begin{array}{l}\text { It is necessary for foreign teachers to have knowledge of the Japanese language to } \\
\text { analyze students' mistakes. }\end{array}$ & 14.3 & 29.9 & 33.2 & 14.0 & 4.7 & 2.7 \\
\hline & $\begin{array}{l}\text { In teaching Japanese students, knowledge of the Japanese language is necessary to } \\
\text { analyze students' mistakes. }\end{array}$ & 11.0 & 18.3 & 35.4 & 13.4 & 14.6 & 6.1 \\
\hline \multirow{2}{*}{ 36. (s } & I want my teacher to explain grammar points in Japanese. & 16.3 & 36.9 & 25.6 & 143 & 4,0 & 1.7 \\
\hline & Knowledge of the Japanese language is useful in explaining grammar points. & 17.1 & 36.6 & 28.0 & 9.8 & 4.9 & 2.4 \\
\hline
\end{tabular}


to a lecture is an effective way of learning English, whereas the teachers' beliefs about this varied. Fewer than half of the teachers saw lectures as an effective means of teaching English and the percentage of teachers who either strongly or moderately agreed with this item was low $(2.4 \%$ and $13.4 \%$ respectively).

\section{Beliefs about Teaching Materials}

Students and teachers also held different opinions regarding appropriate topics for teaching materials (Table 5). More than $95 \%$ of the students supported the idea that the most appropriate topics for learning English deal with everyday life (Item 29). However only $1.2 \%$ of the teachers strongly agreed, $20.7 \%$ moderately agreed, and $40.2 \%$ slightly agreed with this item and $36.7 \%$ held negative attitudes toward this choice of topic. Another discrepancy concerned learning and teaching about social issues (Item 4). More than $66 \%$ of the students agreed that learning about social issues is the most appropriate way to study English, whereas only $48.8 \%$ of the teachers held positive attitudes toward this idea. More than $50 \%$ of the teachers felt negatively about this idea.

There were also some differences in beliefs about the nature of appropriate teaching material. A high percentage of students $(88.1 \%)$ indicated that course material should be up to date (Item 20), and $88.3 \%$ thought that their level of English ability should be the most important consideration when selecting material (Item 34). On the other hand, only $56.2 \%$ of the teachers thought that up-to-date course material is important, while $42.6 \%$ disagreed. However nearly $77 \%$ of the teachers agreed that the ability of the students should be the most important consideration in selecting course material.

\section{Beliefs about Cultural Matters}

As shown in Table 6, the answers of the students and teachers were quite similar for questionnaire items relating to Japanese culture. There were similar responses with regard to the motivation of Japanese students (Item 5): $42.8 \%$ of the students and $45.1 \%$ of the teachers agreed that Japanese students are motivated to study English. Slightly more teachers $(37.6 \%)$ than students (24.6\%) thought that Japanese students can be impolite because they sometimes overgeneralize Western culture (Item 18), although a majority of students and teachers tended to disagree with this assertion. Both students and teachers tended to think that the teacher's authority is respected in the Japanese classroom (Item 26). Both groups tended to believe that it is necessary for foreign teach- 
Table 5: Beliefs about Teaching Materials strongly agree slightly slightly disagree strongly agree

4. (S) Studying about sociaj issues is the most appropriate way to leam English. 10.6 10.6
3.7 24.6 sice isagree disagree

(T) Teaching about social issues is the most appropriate way to teach English

21.3
25.6

6.6
23.2 to Japanese students.

20. (S) The most appropriate materiais are those that are up to date.

(T) In choosing teaching materials, the most important consideration is that they are

29.9

33.9

36.6 up to date.

29. (S) The most appropriate topics in learning English are those dealing with everyday life.

(I) The most appropriste topics for college students in Japan are those dealing with everyday life.

\begin{tabular}{rrrrrr}
38.5 & 39.2 & 17.9 & 2.3 & 0.3 & 0.3 \\
1.2 & 20.7 & 40.2 & 15.9 & 17.1 & 3.7 \\
25.9 & 35.2 & 27.2 & 8.0 & 1.3 & 1.0 \\
8.5 & 35.4 & 32.9 & 17.1 & 6.1 & 0.0 \\
\hline
\end{tabular}

34. (S) When choosing materials, the level of English is the most impontant consideration for teachers.

(I) When choosing teaching materials, the level of English is the most important.

$8.5 \quad 35.4 \quad 32.9$

Note; In some of the items, total percentages do not add up to $100 \%$. This is beciuse some subjects did not respond to all of the items. 
ers to know Japanese culture when interacting with Japanese students (Item 32), but more teachers $(92.7 \%)$ tended to agree with this statement than did students $(81.1 \%)$ and the teachers showed a stronger degree of agreement. Furthermore, more than half of both groups ( $62.2 \%$ of the teachers and $64.8 \%$ of the students) thought that student reticence is a problem in class (Item 24). However, the wording of the statements on the two questionnaires was slightly different so direct comparison is difficult.

\section{Discussion}

This study has identified some discrepancies between Japanese EFL learner and teacher beliefs about English language learning and teaching. A number of students reported that they preferred traditional aspects of language instruction, while the teachers preferred more recent instructional trends. As to what constitutes a traditional approach to language instruction, Renandya, Lim, Leong \& Jacobs (1999) have analyzed the differences between the traditional paradigm and the current communicative paradigm in ELT methodology through a review of the work of Larsen-Freeman (1998), Genesee and Upshur (1996), Nunan (1988), Richards and Rodgers (1986), and Tudor (1996). According to Renandya et al. (1999), the traditional paradigm can be characterized by the following eight characteristics: (a) focus on language, (b) teacher-centeredness, (c) isolated skills, (d) focus on accuracy, (e) discrete point tests, (f) traditional tests, (g) emphasis on product, and (h) individual learning. In contrast, the current communicative paradigm is represented by a different set of characteristics: (a) focus on communication, (b) learner-centeredness, (c) integrated skills, (d) focus on fluency, (e) holistic tests, (f) authentic assessment, (g) emphasis on process, and (h) cooperative learning.

One of the attitudinal gaps identified between teachers and students concerned pronunciation (Table 1, Item 31). The students were quite interested in learning correct pronunciation; however the teachers reported that pronunciation is not strongly emphasized in their classrooms. Perhaps this is because current trends in EFL education focus on the development of communicative competence through integrated skills rather than through the teaching of isolated skills such as pronunciation. Unlike the grammar-translation and audiolingual methods prevalent some decades ago, one of the most important things in communicative language learning and teaching is to get one's message across. In communication a smooth transaction is valued more than linguistic or pronunciation accuracy. However, since students seem to consider pronunciation important, teachers should determine whether 


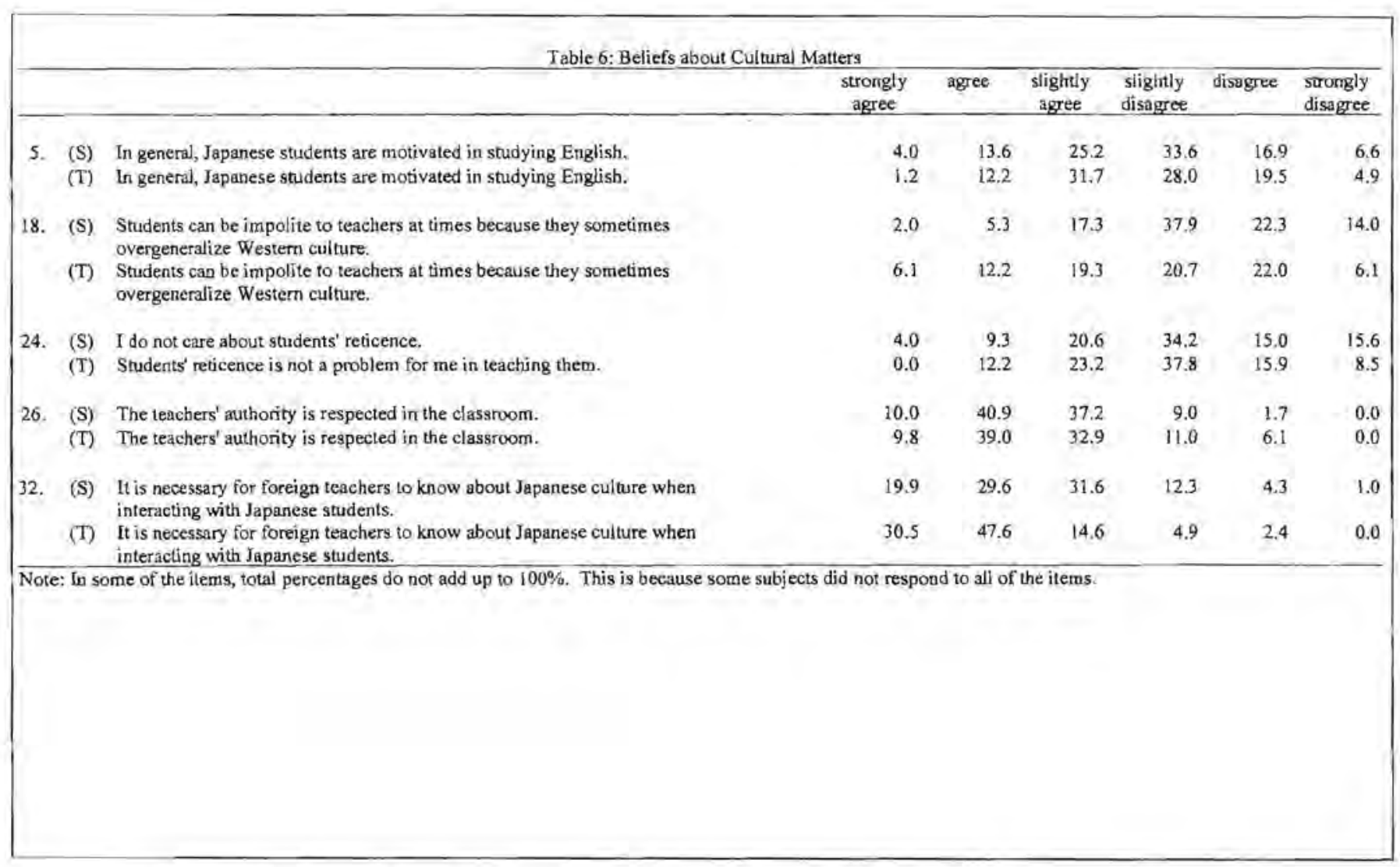


tive reaction to making English compulsory in universities is suggested to be based on or at least reinforced by the popular Japanese belief that kokusaijin (internationally-minded people) should be able to communicate in English because English is an international language.

It is very important for teachers to be aware that some of their students may not be used to or may not prefer the instructional styles they use in class. As mentioned, quite a number of students indicated a strong preference for conservative teaching and learning styles. When students enter university and encounter new teaching and learning styles, they may become anxious. Teachers can play an important part in easing their students' anxiety by explaining how the students can learn more effectively with the new approaches. Alternatively, teachers may also consider modifying their style to remove or lessen student anxiety.

Regarding future directions for research, this study has only identified some beliefs. Most of the questionnaire items used here could be categorized as Wenden's "theorizing" (1986). Further studies should therefore be conducted to examine Wenden's other types of beliefs, for example, "diagnosing" (language proficiency) and "evaluating" (outcome of strategies). In addition, future studies should use other types of questionnaire formats. Open-ended types of questionnaires, for instance, would elicit more authentic and more detailed beliefs.

Teachers should also consider how to integrate their students' beliefs into classroom practice. The results of this study provide some pedagogical suggestions for classroom instruction and curriculum design. As shown, students' beliefs about how they should approach English learning may differ from what teachers and researchers believe. In order for students to gain maximum benefit from the methods that their teachers use, constant assessment of learner beliefs is needed to evaluate and adjust current theories and practice.

\section{Acknowledgments}

This article is based on a presentation given at AlLA'99 in Tokyo. We would like to thank all the participants in our study and the anonymous reviewers of JALT Journal.

Hiroko Matsuura is an associate professor of English and Communication in the Faculty of Economics, Fukushima University, Her research interests include sociolinguistics and interlanguage pragmatics.

Reiko Chiba is a professor of English at Asia University in Tokyo. Her research interests include sociolinguistics and World Englishes. 
Paul Hilderbrandt is a teacher of English at Meiji Gakuin University. He is interested in psycholinguistics, sociolinguistics, and materials development.

\section{References}

Chiba, R, \& Matsuura, H. (1998, November). Native and nonnative ideas about teaching goals of EFL in Japan. Paper presented at the 5th International Conference on World Englishes. University of Illinois.

Ehrman, M., \& Oxford, R. (1990). Aduit language learning styles and strategies in an intensive training setting. The Modem Language Journal, 74, 311-327.

Genesee, F., \& Upshur, J. A. (1996). Classroom-based evaluation in second language education. Cambridge: Cambridge University Press.

Gorsuch, G. J. (1998). Yakudoku EFL instruction in two Japanese high school classrooms: An exploratory study. JALT Journal, 20, 6-32.

Horwitz, E. K. (1985). Using student beliefs about language learning and teaching in the foreign language methods course. Foreign Language Annals, 18, 333-340.

Horwitz, E. K. (1988). The beliefs about language learning of beginning university foreign language students. The Modern Language Journal, 72, 283294.

Larsen-Freeman, D. (1998). Expanding roles of learners and teachers in leamercentered instruction. In W. A. Renandya \& G. M. Jacobs (Eds.), Leamers and language leaming (pp. 207-226). Singapore: SEAMEO-Regional Language Centre.

Ministry of Education. (1999a). Wagakuni no bunkyoshisaku [Educational policies in Japan]. Tokyo: Printing Bureau, Ministry of Finance.

Ministry of Education. (1999b). Global-ka jidai ni motomerareru kotokyoiku no arikata nitsuite [On higher education in the internationalized society]. Retrieved September 2, 2000 on the World Wide Web, http:// www.monbu.go.jp/singi/daigaku/00000353.

Ministry of Education. (2000). Global-ka jidai ni motomerareru kotokyoiku no arikata nitsuite [On higher education in the internationalized society]. Retrieved September 2, 2000 on the World Wide Web, http:// www.monbu.go.jp/singi/daigaku/00000369.

Ministry of Foreign Affairs. (2000). About the JET Program. Retrieved August 28,2000 on the World Wide Web, http://www.mofa.go.jp/__info/visit/jet/ outline html.

Mori, Y. (1999). Epistemological beliefs and language learning beliefs: What do language learners believe about their learning? Language Learning, 49. $377-415$.

Nunan, D. (1988). The leamer-centred curriculum. Cambridge: Cambridge University Press. 
Parmenter, L. (1999). Structuring students' knowledge base of the world: The effects of internationalization on the Japanese school curriculum. Educational Joumal, 27, 13-36.

Reid, J M. (Ed.). (1995). Leaming styles in the ESL/EFL classroom. New York: Heinle \& Heinle.

Renandya, W. A., Lim, W. L., Leong, K. W., \& Jacobs, G. M. (1999). A survey of English language teaching trends and practices in Southeast Asia. Asian Englishes, 2, 37-65.

Richards, J. C, \& Rodgers, T. (1986). Approaches and methods in language teaching: A description and analysis. New York: Cambridge University Press.

Shimizu, K. (1999). Educational dataland 1999-2000. Tokyo: Jijitsushinsha.

Tudor, I. (1996). Leamer-centeredness as language education. Cambridge: Cambridge University Press.

Wenden, A. (1986). What do second-language learners know about their language learning? Applied Linguistics, 7, 186-205.

Wolf Jr., W. C., \& Riordan, K. M. (1991). Foreign language teachers' demographic characteristics: In-service training needs and attitudes toward teaching. Foreign Language Annals, 24, 471 478.

(Received April 6, 2000; revised November 17, 2000) 


\title{
What Counts in the Acquisition and Attrition of Numeral Classifiers?
}

\author{
Lynne Hansen \\ Brigham Young University, Hawaii
}

\author{
Yung-Lin Chen \\ Brigham Young University, Hawaii
}

This study compares second language (L2) acquisition and attrition sequences of the syntax and semantics of numeral classifier systems in light of considerations of markedness, frequency, and the regression hypothesis. In classifier data elicited from English-speaking adult learners and attriters of two East Asia languages, Japanese and Chinese, we find in the attrition of both languages, in both syntax and semantics, a regression of the acquisition sequence. An implicational semantic scale, the Numeral Classifer Accessibility Hierarchy, coinciding closely with the relative frequencies of the classifiers in input, appears to provide a path of least resistance for the learning and the loss of the semantic systems.

本研究では、有標性、頻度、回帰仮説の観点から、助数詞・分類辞を取り上 け、統語的・意味的に第二言語習得・製失の順序を考察した。二種類の言語

(日本語・中国語) について、成人の言語学習者・袈失者加ら助数詞・分類辞 のテータを収集し、二種類の言語の㹂失、統語的・意味的習得と裴失、習得順 位について考察した。含意の意味的スケール、助数詞・分類辞の容認可能性 の階層、インブットに現れる助数詞・分類辞の頻度は互いに関倸しており、阻 害が最小になるような習得過程や、言語坟失過程を示咬していることが考えら れる。

$\mathrm{T}$ his paper examines interlanguage classifier systems, an as pect of second language (L2) semantics and lexicon that has scarcely been touched upon in previous research. The focus is on the accessibility of numeral classifiers in the learning and subsequent forgetting of two East Asian languages by English-speaking adults. The aims of the investigation are (a) to determine the stages of classifier syntax in learning and loss, (b) to examine semantic accessibility in classifier systems in learning and loss, and (c) to explain the findings in light of considerations of markedness, frequency, and the regression hypothesis. A comparison of data from two groups within the same population who learned unrelated languages, Japanese or Chi- 
nese, increases the transparency of the window that is provided into universals in second language progression and regression.

\section{Numeral Classifier Systems}

The languages of the world can be divided into two groups with regard to numeral classifiers: those that have classifiers, such as the majority of languages in East and Southeast Asia, and those that do not, such as most European languages, including English (Allan, 1977). In Japanese and Chinese the numeral classifiers, or "counters" as they are also called, are morphemes which occur adjacent to numerals and categorize the noun referent based on semantic features such as animacy, shape, size, arrangement, and function. A counter is obligatory in a noun phrase containing a numeral, and, as shown in the following examples, occurs between the number and the noun referent:

$\begin{array}{llllll}\text { (1) English } & \text { three } & & \text { books } \\ \text { (2) Japanese } & \begin{array}{l}\text { san } \\ \text { (three }\end{array} & \begin{array}{l}\text { satu } \\ \text { classifier }\end{array} & \begin{array}{l}\text { no } \\ \text { poss. part. }\end{array} & \begin{array}{l}\text { hon } \\ \text { book) } \\ \text { (3) Mandarin }\end{array} \\ \begin{array}{llll}\text { san } \\ \text { (three }\end{array} & \begin{array}{l}\text { ben } \\ \text { classifier }\end{array} & \text { book) }\end{array}$

There are scores of such counters in both Japanese and Chinese which co-occur only with nouns that share the semantic feature specified by that classifier. In the schematic organizations of the Japanese and Mandarin classifier systems shown in Appendix I, we include the particular classifiers that are examined in the present study. While these two systems have many similarities, they do differ in the details of the semantic classifications as well as in the amount of variability allowed in reference. Chinese noun classes are more variable than those in Japanese, with a greater tendency for fuzzy sets that are often mutually overlapping.

The research on the semantics, frequency, and historical development of classifiers in many languages has established an implicational scale of the semantic features of classification (Craig, 1986). This scale is derived from cross-linguistic investigations such as Adams and Conklin's (1973) study of the classifier inventories of 37 Asian languages. This study reports that animacy, in the form of a human/nonhuman distinction or an animate/inanimate distinction, is always encoded. The three basic shape categories of long, round, and flat usually appear also. Secondary parameters, such as rigidity and size, are often found but usually in combination with the primary parameters 